\title{
LESS 1080 BAIT USAGE IN AERIAL OPERATIONS TO CONTROL POSSUMS
}

\author{
D.R. MORGAN 1 , M.D. THOMAS ${ }^{1}$, D. MEENKEN ${ }^{2}$ \\ and P.C. NELSON ${ }^{3}$
}

\author{
${ }^{1}$ Landcare Research, PO Box 69, Lincoln, New Zealand \\ ${ }^{2}$ Wellington Regional Council, PO Box 41, Masterton, New Zealand \\ ${ }^{3}$ Pest Management Services, PO Box 121, Waikanae, New Zealand
}

\begin{abstract}
Field trials showed that high application rates (20-35 kg/ha) of 1080 pellet and carrot baits for possum control were unnecessary, wasteful, and environmentally unsound. Reducing the standard operational rate to 5-10 $\mathrm{kg} / \mathrm{ha}$ has saved, conservatively, $\$ 8.9$ million/year. In our most recent trials, kills averaging $95 \%$ were gained with $2 \mathrm{~kg} / \mathrm{ha}$ indicating further potential savings of $\$ 3$ million/year or more. A new helicopter baitapplication bucket has been developed to overcome the common problem of buckets becoming blocked below rates of 3-4 kg/ha. The new bucket can apply baits uniformly at rates as low as $0.5 \mathrm{~kg} / \mathrm{ha}$, promising not only greater efficiency but enhanced environmental safety.
\end{abstract}

Keywords: Trichosurus vulpecula, possum, pest control, 1080, baits, aerialbaiting

\section{INTRODUCTION}

The brush-tailed possum (Trichosurus vulpecula) is New Zealand's foremost vertebrate pest, damaging large tracts of indigenous vegetation and spreading bovine $\mathrm{Tb}$ to cattle and deer herds. Around $\$ 31 \mathrm{~m}$ is spent annually in controlling possum populations in key areas (Easonet al. 1996). Pest control agencies have, for the last 30 years, favoured the use of aerial poisoning with 1080 baits to rapidly reduce possum populations over areas as large as 20,000 ha. It is especially suitable where inaccessibility of the terrain prevents the use of ground-based control techniques. Currently aerial poisoning is used over about half of the total area where possums are controlled. Operations are conducted using either carrot bait, prepared by dicing carrots and coating them with 1080 , or factory-prepared cereal-based pellet baits with 1080 incorporated. Correctly prepared and delivered, these baits can be expected to reduce possum populations by more than 90\% (Morgan 1982; 1990).

Aerial poisoning operations in the early $1970 \mathrm{~s}$ applied baits at rates of $15-45 \mathrm{~kg} / \mathrm{ha}$ (Batcheler 1978), with pellets generally being applied at lower rates than carrot baits. As possums theoretically need to find and eat only one or two correctly prepared baits (i.e., weighing $6 \mathrm{~g}$ and containing $0.15 \% \mathrm{wt} / \mathrm{wt} 1080$ ) to receive a lethal dose of 1080, and possum population densities typically range from $0.5-25$ possums/ha (Cowan 1990), it would appear that excessive amounts of 1080 bait were used in past control operations. Indeed, application rates often exceeded the biomass of possums being targeted. Because of problems with many small, sub-lethal baits (Batcheler 1982), and large gaps in coverage (Morgan 1994b), excessive amounts of bait were applied so that possums would eventually find and eat a lethal bait. These problems have largely been solved by improved standards of bait preparation and the introduction of GPS-based navigational guidance systems (Morgan 1994a). In recent years, the emphasis has been on further improving the technique and increasing operational efficiency by reducing the amount of bait applied.

Reducing application rates will substantially reduce the cost of bait used and 
associated transport, storage, handling and flying costs. It will also decrease the risk of poisoning non-target organisms (see review by Spurr 1993b) and achieve better compliance with worldwide market demands for minimal use of pesticides in agricultural production (Greig-Smith 1993).

This paper reports a series of field trials that were conducted to help possum control agencies establish the minimum achievable bait application rate necessary for effective control, and to examine the effect of incomplete bait application. The cost-savings that have been gained in possum control by reducing operational application rates of 1080 baits are also reviewed.

\section{Field trials}

\section{METHODS}

Six field trials were conducted in conjunction with possum control agencies to assess effectiveness of different application rates of No. 7 cereal pellet baits (Animal Control Products Ltd., Wanganui). Effectiveness was determined either by the percentage of possums eating non-toxic baits or by the percentage killed using 1080-treated baits. All trials were carried out in winter or early spring.

Baits were applied using a helicopter with an underslung bucket in each trial. The buckets were calibrated to deliver the desired rates by changing the size of the aperture at the base of the bucket to regulate the flow of baits on to the spinning distributor disc. Bait output from the bucket, operating on the ground with the distributor disc stationary, was established at different aperture settings. A known weight of pellets was placed in the bucket and the time for this material to be delivered through the aperture to the disc was recorded by stopwatch. Aperture settings were then selected that gave the desired nominal application rate using the formula (derivation given in Morgan 1994c):

$$
\text { Application rate }(\mathrm{kg} / \mathrm{ha}) \quad=\quad \text { Output rate }(\mathrm{kg} / \mathrm{min}) \times 600
$$

Flying speed $(\mathrm{km} / \mathrm{h}) \mathrm{x}$ swath width $(\mathrm{m})$

Complete coverage of target areas was obtained using helium balloons to mark flight paths in the earliest trial, and navigational guidance systems (Decca Flying Flagman or GPS-based systems) in all other trials.

Non-toxic pellet baits were used in the first three trials. These were surface-treated with $0.1 \%$ w/w rhodamine B dye (ICI Ltd) as a bait marker (Morgan 1981). Baits were applied at rates ranging from $1.5-10 \mathrm{~kg} / \mathrm{ha}$ (Table 1 ) over blocks of approximately 100 ha. The first trial was conducted in a 12-year-old pine plantation at Waimahia State Forest near Taupo where understorey vegetation on the pumice soils was very sparse making baits readily available to possums. Baits were also applied along alternate 100-m swaths in one block to assess the effect of gaps in coverage. The second and third trials were carried out in mature mixed kauri-hardwood forest at Waipoua and Puketi forests, Northland, where understorey vegetation was typically very dense, thus concealing some baits. Gaps were again created in these trials. At Waipoua, a central portion of the 1 square km block (i.e., 100 ha) measuring approximately 300 x 1000 m (i.e., 30 ha) was left untreated, and data were compared for the entire block and the part that was treated. At Puketi alternate $100 \mathrm{~m}$ swaths were left untreated in one block.

After baits had been available to possums for one night, a sample of at least 40 possums was collected from each treatment block by use of cyanide paste (Animal Control Products Ltd) and leg-hold traps 2-5 days after bait was applied. The percentage of possums eating baits in each block was determined from rhodamine dye-marking of the mouth, forepaws and digestive tract (Morgan 1982).

In more recent trials, toxic No. 7 pellets containing $0.15 \%$ w/w 1080 (confirmed by laboratory assay) were applied (Table 1). Two trials were conducted in relatively 'open' pine plantations at Puketiro and Whakatikei, west of Upper Hutt, while the most recent trial was conducted in more densely vegetated native podocarp-hardwood forest near Otaki. Larger blocks of between 140-300 ha were selected for these trials as the effectiveness of the application rates was assessed by the 'trap-catch' method (Warburton 1996). Twenty leghold traps were set at $20 \mathrm{~m}$ intervals along 10 randomly located lines before and after poisoning. After poisoning the lines were relocated parallel to and at least 200 m away from pre-poisoning lines to ensure that an independent estimate of the population surviving 
poisoning was obtained. The mean population reduction was obtained from the reduction obtained from individual pairs of lines.

\section{Operational cost-savings}

Data were obtained from Regional Councils, the Department of Conservation, and several summary reports (Batcheler 1978; Spurr 1993a; Anon. 1994; Brown and Arunchelvam 1995) on application rates and costs for 141 operations between 1973 and 1997. Mean application rates for operations using pellet $(n=90)$ and carrot $(n=51)$ baits were calculated for successive 5-year periods and costs of control/hectare were adjusted to 1997 values using the Consumer Price Index (CPI). Costs included direct operating costs but not overheads.

\section{Field trials}

\section{RESULTS}

Reducing the application rate of baits did not result in poorer possum kills except where coverage was incomplete (Table 1).

TABLE 1: Percentage of possums eating non-toxic baits or percentage of possums killed by toxic baits in field assessments of effectiveness of different application rates of pellets.

\begin{tabular}{|c|c|c|c|c|c|c|c|c|c|}
\hline \multirow[t]{2}{*}{ Site } & \multirow[t]{2}{*}{ Date } & \multirow{2}{*}{$\begin{array}{l}\text { Bait } \\
\text { type }^{1}\end{array}$} & \multicolumn{7}{|c|}{ Application rate (kg/ha) } \\
\hline & & & 10 & 5 & $\begin{array}{c}5 \\
\text { with gap }\end{array}$ & ps) 3.7 & 3 & 2 & 1.5 \\
\hline Waimahia & June 1985 & NT & 95 & 95 & 76 & & 98 & & \\
\hline Waipoua & May 1990 & NT & & 97 & 87 & & & & \\
\hline Puketi & May 1992 & NT & & 83 & 71 & & 84 & & 92 \\
\hline Puketiro & July 1995 & $\mathrm{~T}$ & & 83 & & 93 & & 95 & \\
\hline Whakatikei & June 1996 & $\mathrm{~T}$ & & 97 & & 100 & & 95 & \\
\hline Otaki & Oct 1996 & $\mathrm{~T}$ & & & & 73 & & 87 & \\
\hline $\begin{array}{l}\text { MEAN \% } \\
\text { (S.E.) }\end{array}$ & & & $\begin{array}{l}95.0 \\
(-)\end{array}$ & $\begin{array}{l}91.0 \\
(3.2)\end{array}$ & $\begin{array}{l}78.0 \\
(4.7)\end{array}$ & $\begin{array}{l}88.7 \\
(8.1)\end{array}$ & $\begin{array}{l}91.0 \\
(7.0)\end{array}$ & $\begin{array}{l}92.3 \\
(2.7)\end{array}$ & $\begin{array}{l}92.0 \\
(-)\end{array}$ \\
\hline
\end{tabular}

${ }^{1} \mathrm{NT}=$ Not toxic, $\mathrm{T}=$ Toxic

All application rates gave mean effectiveness within the range 88.7-95.0\%. There was no trend of declining effectiveness when the rate was reduced. In the three trials where gaps were created, mean effectiveness was $78.0 \%$ which was significantly less than the mean effectiveness of $91.7 \%$ in equivalent, completely covered blocks ('paired' $\mathrm{t}=5.0, \mathrm{P}=0.04$, d.f.=2).

\section{Operational cost-savings}

Application rates of baits have declined markedly over the last 20 years (Figs. 1a and b). Typically, pellets are now applied at only a quarter of the rate used in the mid-1970s, while the typical application rate of carrot has also been more than halved. This has provided appreciable cost-savings, particularly for pellet operations as this type of bait comprises a higher proportion of the total cost than carrot bait. At current rates of 5 and $10 \mathrm{~kg} / \mathrm{ha}$ for pellet and carrot baits respectively, savings of around $\$ 50$ and $\$ 30 / \mathrm{ha}$ are being made when compared with application rates of 20 years ago. Although our database is incomplete, it shows that in 1994 pellet and carrot baits were each applied over at least 100,000 and 130,000 ha respectively. This represents a saving of $\$ 8.9$ million in the cost of aerial control for that year compared with the average cost in the mid-1970s.

\section{DISCUSSION}

Aerial application rates of possum baits have declined markedly over the last 20 years providing substantial cost-savings which can be used to extend the area over which 
(a)

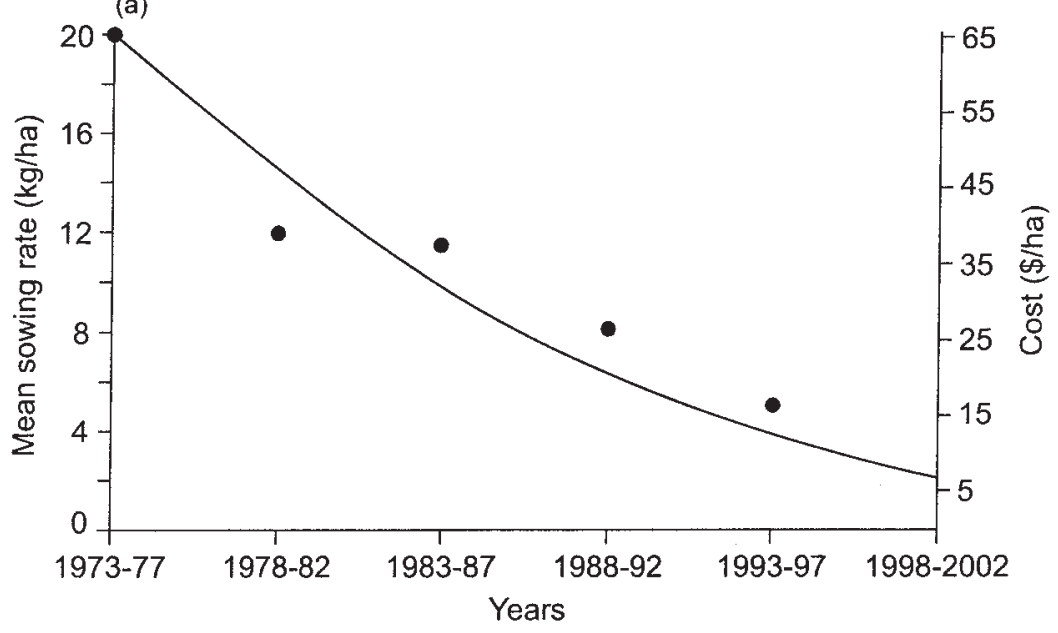

(b)

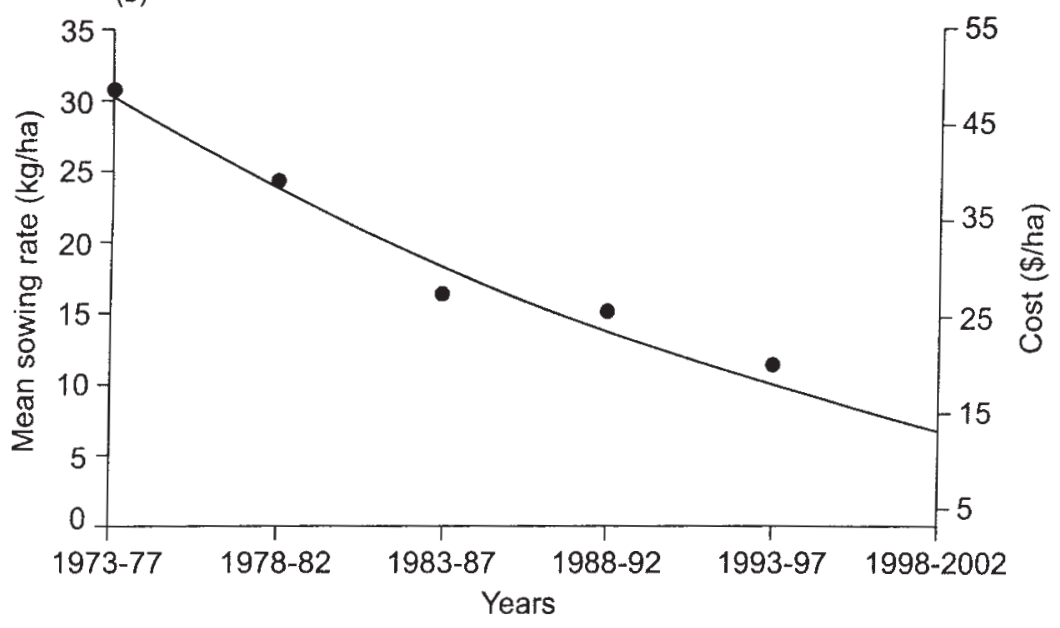

FIGURE 1: The trend (line fitted by eye) in reduced mean application rate and associated CPI-adjusted cost for possum control operations using pellet (a) and carrot (b) baits.

possum populations are controlled. This has occurred in part because improvements in bait quality and application technology have increased the chances of possums finding a lethal quantity of bait, and perhaps in part due to the involvement of possum control agencies in the trials described here. At the present conventional application rate for pellets of $5 \mathrm{~kg} / \mathrm{ha}$, approximately 900 lethal baits/ha are being delivered to populations that number only $0.5-25$ possums /ha (Cowan 1990). It is therefore not surprising that our trials indicate that further reductions to $2 \mathrm{~kg} / \mathrm{ha}$, or lower, should be effective even 
in forest types where thick understorey vegetation may conceal many baits. A further $\$ 3$ million, at least, could be saved annually if rates were lowered to $2 \mathrm{~kg} / \mathrm{ha}$, assuming that 150,000 ha is treated annually with each bait type. However, in some habitats high numbers of other vertebrate pests that may eat baits, such as rodents, deer, and pigs, may make further reductions more risky. The effectiveness of low application rates in such habitats should therefore be assessed.

While further reductions in application rates may be desirable in many situations, machinery that can reliably apply baits at low (i.e. $<5 \mathrm{~kg} / \mathrm{ha}$ ) rates is not readily available. Most helicopter underslung buckets and top-dressing aircraft used in possum control are designed primarily for distributing fertiliser or seed at much higher rates. Even the purpose-built devices available mostly rely on the principle of baits being gravity-fed through an aperture of variable size. This inevitably leads to blockages in flow when the aperture is reduced to a critical size, usually somewhere around rates of 3-4 kg/ha. The new 'SowLow' bucket (patent applied for) developed by Landcare Research avoids this problem by using a metering device, controlled by a variable speed motor, to deliver baits at different rates from a fully open aperture to the spinner disc. Bench testing and preliminary field-testing indicate that the device is capable of applying baits uniformly at rates as low as $0.5 \mathrm{~kg} / \mathrm{ha}$.

In the future it should be possible to accurately distribute (using GPS) 'Quality Assured' baits with a selected field-life at rates as low as $0.5 \mathrm{~kg} / \mathrm{ha}$ (i.e., $100 \mathrm{baits} / \mathrm{ha}$ ). If this proves to be effective, not only will further substantial cost-savings be gained, but the reduced exposure of baits to living and non-living parts of the ecosystem will further enhance the environmental safety of this very efficient control method.

\section{ACKNOWLEDGEMENTS}

The Department of Conservation and the Foundation for Research Science and Technology provided funding for this research. We thank the many Department of Conservation and Regional Council staff who assisted in the trials and provided information on aerial operations, and Mark Wickstrom and Megan Ogle-Mannering for helpful comments on an earlier draft.

\section{REFERENCES}

Anon., 1994. Possum management in New Zealand. Parliamentary Commissioner for the Environment, Wellington. 196p.

Batcheler, C.L., 1978. Compound 1080 - its properties, effectiveness, dangers, and use. NZ Forest Service, Wellington. 68p.

Batcheler, C.L., 1982. Quantifying "bait quality" from number of random encounters required to kill a pest. N.Z. J. Ecol.: 129-139.

Brown, J.A. and Arulchelvam, I.M., 1995. The relative importance of operational factors on the success of aerial possum-control operations. Landcare Research Contract Report LC9596/60. 15p.

Cowan, P.E., 1990. The Handbook of New Zealand Mammals. Oxford University Press, Auckland. 600p.

Eason, C.T, Warburton, B.W. and Gregory, N., 1996. Future directions for toxicology and welfare in possum control. The Roy. Soc. of N.Z. Misc. Series 35: 24-28.

Greig-Smith, P.W., 1993. Killing with care-can pesticides be environmentally friendly? Biologist 40: 132-136.

Morgan, D.R., 1981. Monitoring bait acceptance in brush-tailed possum (Trichosurus vulpecula Kerr) populations: development of a tracer technique.N.Z. J. For. Sci. 11: 271-77.

Morgan, D.R., 1982. Field acceptance of non-toxic and toxic baits by populations of the brushtail possum (Trichosurus vulpecula Kerr). N.Z. J. Ecol. 5: 36-43.

Morgan, D.R., 1990. Behavioural responses of brushtail possums, Trichosurus vulpecula, to baits used in pest control. Aus. Wildl. Res. 17: 601-613.

Morgan, D.R., 1994a. Improved cost-effectiveness and safety of sodium monofluoroacetate (1080) possum control operations. The Roy. Soc. of N.Z. Misc. Series 28: 144-150. 
Morgan, D.R., 1994b. Improving aerial control of possums by precision bait delivery. Proc. 16th Vert. Pest Conf.: 287-292.

Morgan, D.R., 1994c. Improving the efficiency of aerial application of baits for possum control. N.Z. J. Ag. Res. 37: 199-206.

Spurr, E.B., 1993a. Review of known effects of 1080 in possum control operations using carrot and cereal baits on non-target species in New Zealand. Landcare Research Contract Report LC9394/35. 40 p.

Spurr, E.B., 1993b. Review of the impacts on non-target species of sodium monofluoroacetate (1080) in baits used for brushtail possum control in New Zealand. The Roy. Soc.of N.Z. Misc. Series 28: 124-133.

Warburton, B.W., 1996. Trap-catch for monitoring possum populations. Landcare Research Contract Report LC9596/60. 15 p. 